to determine mortalities, and it was only with the application of the mathematical treatment of catch statistics developed for fish stocks that the best yields could be resolved. But this was at the eleventh hour. It might be asked whether earlier numerical assessment of the stocks might not have saved them. It is unlikely: political considerations would probably still have been paramount. Nevertheless, if they are to give sound advice, fisheries scientists must make sure that their science remains in equilibrium; studies in physical and biological and oceanography, to give the essential basic information about the biology of fish and about their physical and biological environments, must be balanced against the less glamorous study of fish population dynamics.

A. J. LEE

\title{
Seals of the World by Gavin Maxwell, with John Stidworthy and David Williams. Constable, 25 s.
}

The first chapter is a straightforward and enjoyably readable introduction to the natural history of seals, their fascinating habits, their extraordinary metabolism by which they adjust perfectly to both hot sun on land and ice and deep diving activity in near-freezing water. The second chapter describes briefly the collision between seals and man, resulting in four of the 32 species of seals, sea-lions and walrus being in grave danger of extinction; one, the Caribbean monk seal, is probably already extinct. The walrus and the Mediterranean monk seal need total protection for a good many years to come, but are not getting it. Most of the remaining species are at present not seriously decreasing, thanks to a new and more enlightened policy of prohibition or regulation of hunting by the governments concerned.

The remaining chapters are potted life histories of each species. I picked out many entertaining and curious items, such as: once-a-week suckling over nearly a year's lactation (Cape fur seal); the walrus wears a natural Mae West (inflatable neck pouches) enabling it to support its great tusks and float upright while dozing at sea; sea elephant intestines can be over an eighth of a mile long. Inevitably, in dipping into the vast literature for their facts, the authors have perpetuated a number of inaccuracies; these ought to be eliminated in future editions of this attractive volume, the sales of which are to benefit the World Wildlife Fund, under whose sponsorship it is published.

R. M. LOCKLEY

\section{Penguins by John Sparks and Tony Soper. David and Charles, Newton Abbot, 45s.}

Although penguins have been subjected to all kinds of intensive study in the last 20 years there has been no general account of their biology; and so much has now been discovered that Murray Levick's delightful Antarctic Penguins no longer tells more than a small fraction of the story.

The author's opening 30-page chapter, 'Penguins as birds', which discusses the main ways in which penguins are adapted to their special way of life, is full of things that will be new to most readers, and offers illuminating comparisons with other birds. The succeeding chapters, on courtship, nest-making, family life, food and predators, although full of interest do not quite maintain the same standard, which is not entirely the fault of the authors. In a group of highly specialised animals such as penguins it is the essential specialisations, which are common to them all and make them different from all other animals, that are the most interesting things about them. When one comes down to smaller differences between the species, especially if they have to be described at second hand, it is hard to maintain the same level of interest, and the material in these middle 
chapters is not always organised so well as it might have been, nor is it free of errors, though most of them are trivial. A fascinating account of the discovery of the various species from the sixteenth century onwards says all that needs to be said about the hideous persecution of penguins in the early days. Here and elsewhere the authors point out that there is no cause for complacency about the future of penguins, even though no species is immediately in danger.

A final chapter gives notes on each of the 17 penguin species, each with a fullpage illustration, by Robert Gillmor, in black and white, yellow and red, which gives almost the full range of colour needed. Other drawings by Robert Gillmor, in black, white and pale blue, are decorative, informative and of the high standard we expect of him, and a fine selection of photographs depicts nearly every species.

D. W. SNOW

\section{Birds of the Antarctic, by Edward Wilson, edited by Brian Roberts.} Blandford Press, 5 gns.

Every so often throughout history a man comes among us who appears nine feet tall. Whether it be through statesmanship, inventiveness, wisdom, courage or skill, such men's greatness is never compared but accepted with gratitude for having raised, each in his individual way, the standards of the human race. Edward Wilson was one of these. Exploration, especially into polar regions, has attracted many such men, scholarly and sensitive with a degree of determination and devotion that surmounts unspeakable hardship. On Captain Scott's fateful 'Terra Nova' expedition of 1910-12, Wilson was chief scientist and doctor Dr Bill. He was also the expedition's cornucopia, dispensing harmony, affection, encouragement, confidence and wise counsel. But there seems little doubt that his own personal reward came from his work and, in particular, his drawing.

Birds of the Antarctic is something of a personal memorial, and Brian Roberts has edited it with a sympathy only possible in someone closely involved with the Antarctic, and with its fauna as closely as with its geography, administration and exploration. Through a common interest he has made it very much Wilson's book, with the finest selection of Wilson drawings ever assembled together, extracts from his diaries, and a précis of his life and work.

The drawings have an extraordinary integrity. Many were done under hopeless conditions and show unmistakeable signs of a struggle but it is this dedication that gives them such value, for each one is an accurate record of fast moving reality. Wilson would have scorned the slick and superficial treatment that so often covers a lack of anatomical understanding. His subject was always master. One can sense a feeling of humility towards it as if accuracy were his way of paying homage to great wonders. His drawings are judged more by human standards than those of present day art. The facts of Wilson's life and work are history, but this chance to see the work of his hand and read his own field notes in his own writing, makes this quotation from Sir Charles Wright so easy to understand: 'We who knew him realised that though he kept himself as much in the background as possible, not a single man on the expedition, from Captain Scott down to myself, ever undertook any serious step without first asking Dr Bill's advice. . . . The best influence and the finest character I for one will ever meet.'

KEITH SHACKLETON

\section{The Mammals of Eastern Canada by Randolf L. Peterson. Oxford University Press, 128s.}

Ten years in the making, this richly illustrated reference book brings together more accurately than ever before information about the distribution, classification, life-history and ecology of the mammals of Eastern Canada. Combining 